https://jurnal.univpgri-

palembang.ac.id/index.php/luminous

\title{
PENINGKATAN PEMAHAMAN KONSEP SISWA MENGGUNAKAN INKUIRI TERBIMBING BERBANTUAN EDMODO
}

\author{
Riani, $L^{1 *}$, Misdalina ${ }^{2}$, dan Sugiarti ${ }^{3}$ \\ ${ }^{1,3}$ Program Studi Pendidikan Fisika, Fakultas Keguruan dan IImu Pendidikan, Universitas PGRI Palembang \\ Palembang, Indonesia \\ Email Penulis Pertama: rianilisa81@gmail.com \\ Email Penulis Ketiga : sugiartialatiq@gmail.com \\ ${ }^{2}$ Program Studi Pendidikan Fisika, Fakultas Keguruan dan IImu Pendidikan, Universitas PGRI Palembang \\ Palembang, Indonesia \\ Email Penulis Kedua : misdalinausman@gmail.com
}

Received: 3101 2021. Accepted: 0202 2021. Published: 15022021

\begin{abstract}
Abstrak
Hasil studi pendahuluan yang dilakukan di SMA PGRI Gelumbang melalui kegiatan observasi dan wawancara menunjukan bahwa kemampuan pemahaman konsep Fisika siswa masih rendah. Kegiatan pembelajaran yang cenderung monoton mengakibatkan siswa kesulitan dalam memahami konsep materi yang diajarkan. Penerapan pembelajaran menggunakan model inkuiri terbimbing berbantuan Edmodo memberikan kesempatan bagi peserta didik untuk dapat berpartisipasi secara aktif dalam belajar. Penelitian ini bertujuan untuk meningkatkan kemampuan pemahaman konsep Fisika. Sampel dalam penelitian ini adalah one group pretestposttest design dengan subjek penelitian peserta didik kelas X IPA 2 di SMA PGRI Gelumbang. Pengumpulan data dilakukan menggunakan soal tes berbentuk essai berjumlah 10 (sepuluh) butir soal. Tes diberikan dalam dua tahap yaitu pretest dan posttest. Hasil penelitian menunjukan terjadi suatu peningkatan terhadap kemampuan pemahaman konsep Fisika siswa dengan perolehan $\mathrm{N}$-gain sebesar 0,74 dalam kategori tinggi.
\end{abstract}

Kata Kunci: Inkuiri Terbimbing, Edmodo, Pemahaman Konsep

\section{PENDAHULUAN}

Dalam kurikulum 2013 pendidik dituntut untuk mampu memberikan suatu pembelajaran yang dapat melibatkan siswa secara aktif dalam proses pembelajaranya sedangkan pendidik hanya berperan sebagai fasilitator. Sebagaimana yang diungkap oleh Sholihah, et al (2018) bahwa, tema K13 yaitu menghasilkan insan Indonesia yang produktif, kreatif, afektif serta inovatif melalui penguatan sikap, keterampilan dan pengetahuan yang terintegrasi. Dengan demikian guru dituntut untuk lebih profesional dalam memberikan pembelajaran dengan memilih model, metode atau media yang sesuai dengan kebutuhan peserta didik.

Salah satu model yang dapat melibatkan siswa secara aktif dalam pembelajaran yaitu model inkuiri terbimbing. Model inkuiri terbimbing merupakan model yang menekankan pada 
keaktifan siswa dalam proses pembelajaran melalui kegiatan praktikum. Sebagaimana Menurut Syarif, et al (2018) bahwa model inkuiri terbimbing merupakan model pembelajaran yang berorientasi pada aktivitas siswa yang aktif dan kreatif menggunakan berbagai sumber belajar untuk menemukan pengetahuan, melalui kegiatan penyelidikan.

Akan tetapi, saat ini masih tedapat pendidik yang masih menggunakan metode ceramah dalam pembelajarannya. Salah satunya yaitu pembelajaran Fisika di SMA PGRI Gelumbang. Dimana berdasarkan hasil studi pendahuluan melalui observasi dan wawancara yang dilakukan, guru masih cenderung menggunakan metode ceramah dalam menyampaikan materi Fisika. sehingga hal ini berakibat pada rendahnya kemampuan pemahaman konsep Fisika siswa tersebut. Dalam hal ini rendahnya kemampuan pemahaman konsep siswa menjadi suatu permasalahan pendidik, karena rendahnya kemampuan pemahaman konsep yang dimiliki siswa dapat mempengaruhi hasil belajar siswa tersebut. Sebagaimana yang diutarakan oleh Sakdiah, et al (2018), bahwa rendahnya hasil belajar yang diperoleh siswa diakibatkan oleh berbagai macam faktor salah satunya adalah rendahnya pemahaman konsep yang dimiliki siswa. Dengan demikian, sangat penting bagi pendidik untuk memastikan bahwa siswa dapat memahami konsep materi yang diajarkannya dengan baik.

Kemampuan pemahaman konsep merupakan suatu kondisi dimana siswa tidak hanya sekedar mengetahui atau mengingat saja, akan tetapi siswa dapat mengungkapkan kembali materi tersebut kedalam bentuk yang lebih mudah untuk dimengerti serta siswa mampu mengaplikasikannya (Pranata, 2016).

Penggunaan model inkuiri terbimbing bukan hanya untuk membuat kegiatan pembelajaran menjadi lebih interaktif, akan tetapi melalui model inkuiri terbimbing siswa akan lebih mudah memahami konsep materi melalui kegiatan kegiatan praktikum yang dilakukan. Sebagaimana yang ditegaskan oleh Tiur.S, et al (2019) bahwa, salah satu model pembelajaran yang dapat digunakan dalam membantu peserta didik menemukan konsep materi yang dipelajarinya yaitu model inkuiri terbimbing, serta menurut Suminten (2015 dikutip dari (Fenica, et al, 2017:3) bahwa, penerapan proses pembelajaran menggunakan model atau metode inkuiri terbimbing dapat membantu meningkatkan pemahaman siswa melalui kegiatan praktikum yang melibatkan siswa secara aktif dalam kegiatan pembelajarannya.

Selain menggunakan model inkuiri terbimbing dalam pembelajaran Fisika, peneliti juga menggunakan media untuk membantu peneliti dalam mencapai tujuan pembelajaran. sebagaimana fungsi dari media menurut Suryani \& Agung (2012) yaitu media pembelajaran adalah suatu alat bantu yang berfngsi untuk mendukung pelaksanaan belajar mengajar dalam upaya mencapai tujuan pembelajaran. Dalam hal ini, media yang digunakan dalam peneltian adalah aplikasi Edmodo. Edmodo merupakan suatu media pembelajaran berbasis internet yang memang diperuntukkan dalam dunia pendidikan, karena Edmodo memiliki berbagai macam fitur yang mendukung kegiatan pembelajaran dan memudahkan pendidik dalam menyampaikan materi pembelajaranya. Sebagaimana menurut Kurniasih, et al (2016) bahwa Edmodo adalah aplikasi berbasis media sosial yang dapat digunakan oleh guru dan siswa untuk berbagi ide, informasi atau tugas terkait kegiatan pembelajaran, melalui Edmodo guru dan siswa dapat saling berinteraksi dimanapun dan kapanpun, karena aplikasi ini mirip seperti facebook yang mudah diakses dan digunakan oleh siswa.

Berdasarkan uraian di atas, adapun rumusan masalah dalam penelitian ini yaitu adakah pengaruh model inkuiri terbimbing berbantuan Edmodo terhadap pemahaman konsep Fisika siswa. Dengan demikian, tujuan dalam penelitian ini adalah untuk mengetahui adakah pengaruh model inkuiri terbimbing berbantuan Edmodo terhadap kemampuan pemahaman konsep Fisika siswa. Melalui 
penelitian ini penulis berharap terdapat pengaruh model inkuiri terbimbing berbantuan Edmodo terhadap kemampuan pemahaman konsep Fisika siswa.

\section{METODE}

Sampel penelitian ini yaitu one group pretest-posttest design dengan menggunakan satu subjek penelitian yaitu kelas X IPA 2 di SMA PGRI Gelumbang. Subjek penelitian berjumlah 32 orang siswa, yang terdiri dari 18 orang laki-laki dan 14 orang perempuan.

Instrumen penilaian yang digunakan dalam penelitian ini yaitu tes soal berbentuk essai dengan jumlah 10 (sepuluh) butir soal. Tes soal diberikan dalam dua tahap, yaitu tahap pretest dan tahap posttest.

$$
O_{1} \times O_{2}
$$

Keterangan:

O1 adalah tes awal (pretest) untuk mengetahui kemampuan pemahaman konsep awal siswa

$X$ adalah perlakuan yang diberikan pada subjek penelitian dengan menerapkan pembelajaran menggunakan model inkuiri terbimbing berbantuan Edmodo.

O2 adalah tes akhir (posttest) yang diberikan pada subjek penelitian setelah diterapkan pembelajaran menggunakan model inkuiri terbimbing berbantuan Edmodo.

Untuk mengetahui adakah pengaruh model inkuiri terbimbing berbantuan Edmodo terhadap kemampuan pemahaman konsep Fisika siswa setelah mengikuti pembelajaran, dalam hal ini dilakukan perhitungan terhadap nilai hasil pretest dan posttest siswa menggunakan persamaan dari Aqib, et al (2016). Sebagai berikut.

$$
\text { Nilai }=\frac{\text { jumlah skor yang diperoleh siswa }}{\text { jumlah skor maksimum }} \times 100
$$

Sumber: modifikasi dari Aqib, et al (2016)

Setelah diperoleh nilai pretest dan posttest dari masing-masing siswa, kemudian dilakukan perhitungan menggunakan persamaan $\mathrm{N}$-gain dari Alfiyanti, et al (2018), sebagai berikut.

$$
\text { Gain ternormalisasi }<\mathrm{g}\rangle=\frac{\text { skor posttest }- \text { skor pretest }}{100-\text { skor pretest }}
$$

Sumber : Alfiyanti, et al (2018)

Setelah rata-rata $\mathrm{N}$-gain siswa diperoleh. Maka, interprestasi $\mathrm{N}$-gain siswa dapat ditentukan berdasarkan tabel berikut ini.

Tabel 1. Interprestasi N-Gain Siswa

\begin{tabular}{c|c}
\hline Gain & Kriteria Interprestasi \\
\hline$(\mathrm{g})>0,7$ & Tinggi \\
\hline $0,7>(\mathrm{g})>0,3$ & Sedang \\
\hline$(\mathrm{g})<0,3$ & Rendah \\
\hline
\end{tabular}

Sumber: Alfiyanti, et al (2018)

\section{HASIL DAN PEMBAHASAN}

Setelah mengikuti pembelajaran menggunakan model inkuiri terbimbing berbantuan Edmodo pada subjek penelitian, terdapat suatu peningkatan dari perbandingan nilai hasil pretest dan postest yang diperoleh siswa. Berikut ini tabel data interval nilai pretest dan posttest siswa kelas X IPA 2 di SMA PGRI Gelumbang.

\section{Tabel 2. Data Interval Nilai Pretest Siswa}

\begin{tabular}{c|c|c}
\hline No & Rentang Nilai & Jumlah Siswa \\
\hline 1 & $15-20$ & 11 \\
\hline 2 & $21-25$ & 11 \\
\hline 3 & $.26-30$ & 8 \\
\hline 4 & $31-40$ & 2 \\
\hline \multicolumn{2}{|c}{ Jumlah } & $\mathbf{3 2}$ \\
\hline
\end{tabular}

Berdasarkan data interval nilai pretest pada tabel di atas diketahui bahwa semua siswa memperoleh nilai di bawah KKM yang ditentukan sekolah. Dengan demikian dapat disimpulkan bahwa kemampuan pemahaman konsep Fisika siswa masih rendah.

Tabel 3. Data Interval Nilai Posttest Siswa

\begin{tabular}{c|c|c}
\hline No & Rentang Nilai & Jumlah Siswa \\
\hline 1 & $50-60$ & 1 \\
\hline 2 & $61-70$ & 1 \\
\hline 3 & $71-80$ & 15 \\
\hline 4 & $81-90$ & 13 \\
\hline
\end{tabular}




\begin{tabular}{c|c|c}
\hline 5 & $91-100$ & 2 \\
\hline \multicolumn{2}{c|}{ Jumlah } & $\mathbf{3 2}$ \\
\hline
\end{tabular}

Berdasarkan data interval nilai posttest pada tabel di atas diketahui bahwa masih terdapat 2 orang siswa yang tidak mencapai KKM. Sedangkan 30 orang siswa dinyatakan telah mencapai KKM yang ditentukan sekolah.

Setelah nilai pretest dan postest siswa diperoleh, maka dilakukan perhitungan menggunakan persamaan $\mathrm{N}$-gain untuk mengetahui adakah peningkatan pemahaman konsep Fisika siswa setelah mengikuti pembelajaran menggunakan model inkuiri terbimbing berbantuan Edmodo. Berikut ini tabel rekapitulasi N-gain siswa.

Tabel 4. Rekapitulasi Data N-Gain Siswa

\begin{tabular}{|l|c|c|c|}
\hline $\begin{array}{c}\text { Jumlah N- } \\
\text { Gain }\end{array}$ & $\begin{array}{c}\text { Indikator } \\
\text { Interpres } \\
\text { tasi N- } \\
\text { Gain }\end{array}$ & $\begin{array}{c}\text { Freku } \\
\text { ensi } \\
\text { N- } \\
\text { Gain } \\
\text { siswa }\end{array}$ & $\begin{array}{c}\text { Interpres } \\
\text { tasi } \\
\text { N-Gain }\end{array}$ \\
\hline \multirow{2}{*}{23,61} & $(\mathrm{G})>0,7$ & 23 & Tinggi \\
\cline { 2 - 4 } & $\begin{array}{c}0,7>(\mathrm{G}) \\
>0,3\end{array}$ & 9 & Sedang \\
\cline { 2 - 4 } & $(\mathrm{G})<0,3$ & & Rendah \\
\hline $\begin{array}{l}\text { Rata-Rata } \\
\text { N-Gain = } \\
\mathbf{0 , 7 4}\end{array}$ & \multicolumn{3}{|c|}{ Tinggi } \\
\hline
\end{tabular}

Berdasarkan data hasil nilai $N$-gain masing-masing siswa kelas X IPA 2 SMA PGRI Gelumbang diperoleh hasil bahwa sebanyak 9 orang siswa dikategorikan memiliki kemampuan pemahaman konsep yang sedang dan sebanyak 23 orang siswa dikategorikan memiliki kemampuan pemahaman konsep yang tinggi. Dengan demikian diperoleh nilai rata-rata $\mathrm{N}$-gain sebesar 0,74 dan dikategorikan tinggi. Maka dapat disimpulkan bahwa terdapat pengaruh model inkuiri terbimbing berbantuan Edmodo terhadap kemampuan pemahaman konsep Fisika siswa.

Penelitian yang serupa sebelumnya pernah dilakukan oleh Sakdiah et al (2015), dalam penelitiannya diperoleh hasil yaitu terdapat peningkatan terhadap pemahaman konsep Fisika siswa sebesar 0,70 dengan kategori tinggi. setelah diterapkannya pembelajaran menggunakan model inkuiri terbimbing. Selanjutnya terdapat juga penelitian yng dilakukan oleh Ratnawati (2020), dalam penelitiannya diperoleh hasil bahwa terjadi peningkatan terhadap pemahaman konsep siswa dengan perolehan $\mathrm{N}$-gain 0,50 dalam kategori sedang, setelah diterapkannya pembelajaran menggunakan bahan ajar berbasis problem posing berbantuan Edmodo. Berdasarkan penelitian yang telah dilakukan oleh peneliti di atas, dapat kita simpulkan bahwa penerapan pembelajaran menggunakan model inkuiri terbimbing berbantuan Edmodo lebih efektif dalam meningkatkan kemampuan pemahaman konsep siswa, dengan perolehan $\mathrm{N}$-gain siswa pada subjek penelitian kelas X IPA 2 di SMA PGRI Gelumbang sebesar 0,74 dalam kategori tinggi.

\section{SIMPULAN}

Berdasarkan hasil dan pembahasan di atas, disimpulkan bahwa penerapan pembelajaran menggunakan model inkuiri terbimbing berbantuan Edmodo dapat meningkatkan kemampuan pemahaman kosep Fisika siswa kelas X IPA 2 di SMA PGRI Gelumbang dengan perolehan rerata $\mathrm{N}$-Gain sebesar 0,74 dalam kategori tinggi.

\section{UCAPAN TERIMA KASIH}

Terimakasih penulis ucapkan kepada pihak-pihak yang telah membantu penulis dalam menyelesaian artikel ini.

\section{DAFTAR PUSTAKA}

Tiur.S, N., Sari, Y. S., \& Darvina, Y. (2019). Analisis Uji Validitas Lks Berorientasi Hots Dalam Model Inkuiriterbimbing Pada Materi Fluida Statik Dikelas Xi Fisika Sma/Ma. Pillar Of Physics Education, 12, 673-680.

Aqib, Z., Jairoyah, S., Diniati, E., \& Khotimah, K. (2016). Penelitian Tindakan Kelas. Bandung: Yrama Widya. 41 
Fenica, I., Muderawan, W., \& Widiartini, P. (2017). Implementasi Model Pembelajaran Inkuiri Untuk Meningkatkan Aktivitas Belajar Siswa Pada Mata Pelajaran Kimia. Pendidikan Kimia Indonesia, 1, 1-6.

Pranata, E. (2016, Maret). Implementasi Model Pembelajaran Group Investigation (Gi) Berbantuan Alat Peraga Untuk Meningkatkan Kemampuan Pemahaman Konsep Matematika. Jpmi, 1, 34-38.

Sakdiah, Mursai, \& Syukri, M. (2018). Penerapan Model Inkuiri Terbimbing Untuk Meningkatkan Pemahaman Konsep Dan Kps Pada Materi Listrik Dinamis Siswa Smp. JIPI, 2, 41-49.

Alifiyanti, I. F., Afifah, H. F., \& Ramadoan, N. (2018). Pemanfaatan Learning Management System (LMS) Berbasis Edmodo Materi Fluida Dinamis Untuk Peningkatan Minat Dan Prestasi Belajar Fisika Siswa Sekolah Menengah., (Pp. 155162). Yogyakarta.

Sholihah, M., Saddhono, K., \& Anindyarini, A. (2018, April). Implementasi Kurikulum 2013 Dalam Pembelajaran Bahasa Indonesia Didalam Dan Luar Negeri (Studi Kasus Pembelajaran Teks Biografi Di Sma Negeri 1 Surakarta Dan Sekolah Indonesia Singapura). Basastra, 6, 184-199.

Syarif, D. M., Putra, A., \& Dwiridal, L. (2018, Oktober). Analisis Kelayakan Perangkat Pembelajaran Fisika Berorientasi Inkuiri Terbimbing Pada Materi Hukum Newton Tentang Gerak Untuk Pembelajaran Fisika Di Kelas X Sma/Ma. Pillar Of Physics Education, 11, 34.

Suryani, N., \& Agung, L. (2012). Strategi Belajar Mengajar. Yogyakarta: Ombak. 43.

Kurniasih, R., Sujadi, I., \& Subanti, S. (2016, Desember). Pengembangan Bahan Ajar Dengan Edmodo Untuk Meningkatkan Level Berfikir Probabilistik Siswa Kelas Viii Smp Negeri 12 Surakarta. Jurnal Elektronik Pembelajaran Matematika, 4, 961-972.

Ratnawati, F.A. (2020, Juni), Pengembangan Bahan Ajar Berbasis Pembelajaran Problem Posing Berbantuan Edmodo Untuk Meningkatkan Pemahaman Konsep Peserta Didik Pada Materi Fluida Dinamis. JPEP, 2, 9-23. 